\title{
Understanding the illiberal turn: Democratic backsliding in the Czech Republic*
}

For two decades after the collapse of communism, scholars tended to identify a trend of democratic progress on the part of states in East Central Europe joining the European Union (EU). There were setbacks and, crucially, tremendous variation in how and how well - democratic institutions and party competition developed over time. This included such basic anchors of democracy as political liberties and the rule of law. Still, the broad picture was one of democratic progress. Today, perhaps echoing broader political trends in the wider transatlantic world (Levitsky and Ziblatt 2018), the narrative of progress in the region is dead, replaced by democratic backsliding - and even sliding into authoritarianism. What is especially jarring is that early standard bearers of democratisation in the region - Hungary and Poland - are leading the way. Moreover, since coming to power, the Hungarian and Polish ruling parties have had a remarkably similar playbook centred on concentrating political and economic power in the name of the nation. Scholars today tend to observe democratic difficulties across East Central Europe through the prism of these two states, viewing other states in the region as a kind of Hungary or Poland writ small (Mueller 2014).

Our goal is to explore to what extent political developments in another key frontrunner in post-communist democratisation, the Czech Republic, fit this backsliding mould. Our analysis centres on the ANO movement, founded in 2011 and led by the billionaire Andrej Babiš. ANO broke through in the October 2013 Czech elections,

\footnotetext{
*We would like to thank Lenka Buštíková, Béla Greskovits, Tim Haughton, and Solveig Richter for their helpful comments on earlier versions of this article.
} 
receiving $18.65 \%$ of the vote at the expense of established right-wing and left-wing parties to become the second largest grouping in the country. It ran such a successful campaign by accusing established parties of incompetence and corruption, and promising that Babiš would run the state "efficiently" like a business (Havlík 2015). In January 2014 ANO entered an uneasy centre-left coalition with the Social Democrats (Česká strana sociálně demokratická, ČSSD), who had narrowly topped the poll. Babiš held the post of finance minister until May 2017 when he was ousted from government over allegations of tax avoidance and fraudulently claiming EU subsidies, for which he was later indicted.

ANO went on to win the October 2017 elections decisively with $29.6 \%$ of the vote, receiving more than twice as many votes as the next biggest vote-getter, the centre-right Civic Democratic Party (ODS) with $11.3 \%$. It won 78 of 200 mandates. In total, nine parties entered parliament, making ANO, in parliamentary terms, the most dominant party in the history of the independent Czech Republic. However, it again fell well short of a parliamentary majority and struggled to find coalition partners as smaller parties feared that they would be dominated in government by ANO, or objected to Babiš as a potential prime minister because he faced an unresolved criminal indictment for EU subsidy fraud. ${ }^{1}$ ANO thus formed a one-party minority administration on 13 December 2017, but lost a vote of confidence on 16 January. At the time of writing (June 2018) ANO was seeking to form a minority coalition with the Social Democrats with external parliamentary support from the Communist Party (Komunistická strana Čech a Moravy, KSČM) (see Pehe 2018).

ANO's rise nevertheless represents a decisive shift in the evolution of Czech democracy towards a form of "populist democracy" (Mair 2002; Pappas 2014). It marks the death knell of the Czech Republic's previously stable party system, outwardly akin to 
those traditionally found in Western Europe. The Czech party system had been dominated by a set of four well-established parties - the free-market conservative Civic Democrats (Občanská demokratická strana, ODS), Social Democrats, Communists and Christian Democrats - and structured by a unidimensional pattern of competition centred on distributional issues (Deegan-Krause 2006, Deegan-Krause and Haughton 2010; Havlík and Voda 2018). Observers have long noted the irony and perhaps the genius of one of the most powerful oligarchs in the Czech Republic using an anti-corruption platform to win and maintain power even while beset with corruption and conflict of interest scandals.

Many observers, however, identify Babiš not simply as a paradoxical populist disruptor but as a potentially authoritarian leader whose rise to power is part of a wider trend towards 'democratic backsliding' in East Central Europe (Patočka 2017). Some have speculated that, working in tandem with the country's president Miloš Zeman, as Prime Minister Babiš will start to dismantle liberal democracy in ways paralleling political changes in Hungary and Poland. ${ }^{2}$ Although ANO's 2017 election victory falls short of the absolute parliamentary majorities won by Fidesz in Hungary in 2010 and Law and Justice (Prawo i Sprawiedliwość, PiS) in Poland in 2015, some parallels are already impossible to miss: the rise of a dominant party with a populist ideology; the decline of the traditional left; and the rise of minor parties and movements positioned at opposite (radical right and social-liberal) wings of the cultural (gal-tan) divide (Rovny 2017).

In this article, we consider to what extent the rise of Babiš and his party is mirroring the initial stages of democratic backsliding by dominant illiberal governing parties in Hungary and Poland: Are there meaningful parallels between the conservative national populism of Viktor Orbán’s Fidesz and Jarosław Kaczyński’s PiS, on the one hand, and 
the more technocratic populism of Babišs's ANO, on the other? Is Babiš concentrating different forms of power in different ways, but with similar results? Or in similar ways but with different results? Does capturing parts of the economy and the state using informal and formal power channelled through a vast business empire offer an alternative route to backsliding?

We find that ANO comes up short ideologically compared to Fidesz and PiS, because it lacks a powerful narrative of Czech nationalism. And while there are tactics and forms of concentrating power common to all three, the timing and sequencing have been different: The Fidesz party led by Orbán built up a political and later social organisation before winning a watershed election. After winning, Orbán implemented a strategy of 'illiberal political economy,' media control, and institutional re-engineering to consolidate power. In contrast, Babiš accumulated tremendous economic and political power as an oligarch first, and then multiplied that power by creating the ANO party, by becoming a media magnate, and by exploiting opportunities in government while ANO served as a junior coalition partner. While ANO's rise is not underpinned by a grandiose illiberal nationalism and typically seeks to co-opt opponents from a position of strength, rather than to confront them, the concentration of power by Babiš in the name of efficiency may represent a quieter politics of backsliding that is just as consequential in the longer term.

This article is divided into four parts. First, we survey the literature on democratic backsliding and consider how the Czech case compares to the paradigmatic cases of Hungary and Poland. Second, given the stress in much of the literature on the populist character of the threat to liberal democracy, we explore the 'ideology’ of Andrej Babiš, including his views on democracy and political reform. Third, we consider alternative 
routes to democratic backsliding. We examine the concentration of different forms of power in the hands of Babiš in the years before the critical October 2017 elections as a potential 'side door' to backsliding. We survey the influence of ANO on the economy, government institutions, the media, and civil society - and the linkages among them. We conclude with some reflections on the future direction of Czech democracy and the implications of the Czech case for wider debates about democratic backsliding in ECE.

\section{Backsliding and the erosion of democracy in CEE}

What is democratic backsliding? Although often used broadly to express frustration with the quality of government, scholars do use the term more precisely to refer to changes in formal or informal institutions that move the polity in the direction of a hybrid or authoritarian regime (Erdman 2011; Dresden and Howard 2016; Sitter et al 2016). Democratic backsliding means that existing power-holders drive a gradual process of democratic regression, and not that outsiders cause a sudden democratic breakdown, as in a classic coup d'état. Nancy Bermeo defines democratic backsliding more precisely as "the state-led debilitation or elimination of any of the political institutions that sustain an existing democracy" (Bermeo 2016, 5 emphasis added; see also Greskovits 2015; Cassani and Tomini 2018). The most common vehicle for backsliding is "executive aggrandisement," a model that accurately captures the trajectory of political change in Hungary since 2010, in Poland since 2015, and in Macedonia after 2008 (Crowther 2017; see also Coppedge 2017). The elected incumbent concentrates political (and later economic) power by stripping away or neutralising constitutional and institutional checks and balances and alternative centres of social power. Targets typically include: 
constitutional courts and the judiciary; the media; top appointments to state-owned companies and agencies; educational and cultural institutions; and rules governing elections, party funding, and campaigning. Backsliding governments capture and use existing institutions and regulatory mechanisms instead of engaging in overtly antidemocratic manoeuvres. Although a relatively short-term process, backsliding is "death by a thousand cuts" (Bermeo 2016), the creation of a 'Frankenstate' in which individually unproblematic measures are combined for a deeply illiberal effect (Scheppele 2013).

Post-communist EU members and candidates that are suffering from such acute democratic backsliding have so far shared two key characteristics. First, governing parties embrace intense if not extreme populist appeals to safeguard the interests of "the people" and "the nation" from opposition elites, outsiders, traitors and foreigners (Grzymala-Busse 2017). In Hungary and Poland Fidesz and PiS, respectively, well-established and ostensibly mainstream conservative groupings, won big in elections by capitalising on popular frustration with corruption, austerity or the uneven benefits of growth. In office, they have called for a return to national grandeur and conservative social values, and promised to defend the nation from liberals, the ex-communist left, foreign-owned big business, and the EU. Political competition on socioeconomic issues has thus been eclipsed by or subsumed into competition on identity and values (Polk et. al. 2017; Vachudova 2017).

The result is striking - and intentional - polarisation in the party system on the social liberal (gal-tan) axis, often radicalising and intensifying earlier divisions. It is by claiming to defend the nation that the leaders of these ruling parties built the political cover to concentrate power and dismantle liberal checks and balances. They also put in place a more centralised, illiberal model of political economy that serves to shore up and grow 
their political power (Scheiring 2015). Xenophobic outbursts become a tool for delegitimising opponents as outsiders who work against the interests of ordinary people and who do not belong to "the nation." Zsolt Enyedi (2016) combines these two ideas suggesting - again through the prism of the Hungarian case - that the polarisation that sustains backsliding is, in turn, sustained by the relatively well-institutionalised character of the conservative-national parties that spearhead it.

Second, in broad terms, it is also fair to argue that both Fidesz and PiS came to power on the strength of their political organisation and implantation in civil society - and that economic power has come mainly after watershed elections brought them to power. ${ }^{3}$ Both Fidesz and PiS had for years organised and drawn strength from conservative civil society by co-opting existing right-wing civic groups and by developing their own stridently partisan groups. ${ }^{4}$ This was especially marked in Hungary where the Civic Circles acquired the character of a mass social movement (Greskovits 2017). Both PiS and Fidesz were also assiduous in cultivating and building up a conservative media base, and using it to delegitimise opposing parties, groups, and institutions (Balogh 2010; Dzięciołowski 2017; Sadecka 2018).

\section{The Czech Republic: resisting backsliding so far?}

To what extent does the rise of ANO in the Czech Republic fit this paradigm derived from the Hungarian and Polish cases? Over the years, scholars have repeatedly shed light on problems of poor political governance and the middling quality of democratic representation in the Czech Republic, some tracing these to weak mass-elite linkages or the unresponsiveness of governing elites (Roberts 2010; 2016a); others to the failure of 
institutions to engineer cohesive majority coalitions (Havlík and Kopeček 2008); and still others to lacklustre political competition, weak civil society that enabled corruption, and bad governance (Vachudova 2005, 2015; Grzymala-Busse 2008; Innes 2014, 2016).

There has, however, rarely been any question, about the stability or integrity of Czech democracy as a regime (though Klíma [2015] is a notable exception). While the Great Recession stemming from the 2008 financial crisis did impact established Czech parties, it did not produce a swing towards the conservative nationalist right, but instead the breakthrough of new "centrist populist" anti-corruption parties, including ANO in 2013 (Havlík and Hloušek 2014; Havlík 2015). Scholars considered such parties as deleterious for the quality of representation and accountability, but ultimately ephemeral, and unthreatening to democracy as a regime (Haughton and Deegan-Krause 2015; Hanley and Sikk 2016).

The Czech Republic still appears in 2017 as a robust democracy in terms of its formal institutions. Indices of democracy and governance such as Bertelsmann, Freedom House, Nations in Transit and V-Dem classify the Czech Republic as a secure and, in regional terms, high-performing democracy (Bernhard 2017). ${ }^{5}$ The Czech Republic enjoys a broadly 'power dispersing' democratic model including proportional representation, a strong upper house, an independent central bank, and a constitution that is difficult to change (Roberts 2006). These seem to be a reasonable fit for a small, ethnically homogeneous post-communist society. Only two recent changes have made Czech institutions more majoritarian: a dilution of the proportionality of the electoral system in 2000; and the introduction of direct elections for the presidency (Kopecký 2004). 
Alongside the rise of ANO, the directly elected presidency has posed perhaps the most serious challenge to Czech democracy since 1989. Although a former leader of the mainstream Czech Social Democratic Party (1992-2000) and an ex-prime minster (19982002), Zeman metamorphosed into an illiberal national-populist after returning from retirement to win the presidential election in 2013. He desires to remake the Czech political system along more presidential lines, following in the footsteps of his predecessor, Václav Klaus. ${ }^{6}$ Zeman has aligned himself with the illiberal governments of Poland and Hungary, publicly praised Vladimir Putin, and sought to expand trade and diplomatic links with China, Russia, and the former Soviet region. He has expressed stridently anti-Islamic and anti-refugee views that have intentionally spread fear and hatred of refugees coming to Europe.

Zeman has also blatantly challenged both the letter and the spirit of the Czech Constitution. Although the Czech Republic is a parliamentary democracy, following the collapse of a centre-right government in May 2013, Zeman appointed a "technocratic" caretaker government of political cronies over the heads of the country's party leaders. The relatively strong position of political parties and of the Constitutional Court, however, quickly curtailed Zeman's ambitions: The parties used their powers to dissolve parliament to end Zeman's 'technocratic' government, resulting in early elections in which his presidential party, the Citizens' Rights Party (Strana práv občanů, SPO) performed poorly. Zeman has also stated his belief - flatly contradicted by constitutional lawyers - that a 'broad interpretation' of the Constitution allows him to dismiss a prime minister. To this end, in May 2017, Zeman suggested that he could accept the planned resignation of Prime Minister Sobotka (later withdrawn) without this triggering the resignation of the whole 
government. Zeman's abortive attempts to assert his power fit the backsliding template of executive aggrandisement, often triggered by elected presidents. But these attempts were, in the end, easily contained by Czech institutions and by the party-centredness of the Czech political system. It turned out that the Czech presidency had no real executive powers to be aggrandised (Kopeček 2017: 225-240).

\section{The populist ideology of ANO and Andrej Babiš}

Backsliding in ECE and beyond has often been linked to ruling populist parties that combine scepticism towards the market with nationalism and social-authoritarianism (lefttan). In contrast, ANO is notionally a liberal party stressing political reform, and a full member of the European liberal grouping ALDE since November 2014. If anything, its hallmark is the absence of ideology (Klimeš 2016).

After its breakthrough in 2013, ANO did not attempt to 'normalise' itself by adopting a more conventional left-right ideology. It retained instead a peculiar brand of populist appeal based on defending ordinary people from 'traditional parties'. In its successful election campaigns in both 2013 and 2017, ANO, whose name means 'YES' in Czech, pitched itself as a non-ideological citizens' movement of practical doers ('We're not politicians, we do work') with a vague rhetoric of positive change ('Yes, things will get better'). ${ }^{7}$ However, its official positions were simply the pronouncements of key individuals, usually of Babiš himself, often delivered in off-the-cuff remarks to the media. Even when expressed more formally, the party's principles are often stated only in brief, vague, and anodyne terms. In 2013 ANO had broadly right-leaning, pro-market positions on the economy and a neutral stance on socio-cultural issues relating to gender, sexuality, 
and the family. It offered in some ways an economically liberal vision of empowered citizen-consumers, e-government, and a 'sharing economy'. Its 2017 electoral programme (ANO 2017) contained a mass of policy detail, often dealing with modernising the public administration.

Yet ANO shares with illiberal governing parties in backsliding CEE states an essentially populist framing of politics (Mudde 2004; Kaltwasser 2012). ANO depicts itself as a citizens' movement of non-politicians championing the interests of the people against a cabal of corrupt and inefficient 'traditional' parties led by professional politicians (Havlík 2015). This has been described as a 'centrist' (Havlík and Voda 2018) 'managerial' (Císař 2017) or 'technocratic' (Bustikova and Guasti 2018) populism. Yet Babiš goes further. He entered the 2017 election campaign complaining bitterly that he was being unfairly persecuted and silenced by the establishment - which he previously termed 'the matrix' including the media, traditional parties and many other 'forces' in Czech society. ANO rejects its rivals as corrupt and criminal. And it promotes an anti-political technocratic view of government as the search for business-like efficient solutions, embodied in Babiš‘s promise to run the Czech Republic like a firm (Bustikova and Guasti 2018). This adds up to a rejection of pluralism and contains the seeds of authoritarianism.

Andrej Babišss 2017 book What I Dream About When I Happen to be Sleeping - a personal vision for Czech democracy - offers his more sweeping anti-political, populist platform for political change: a strongly majoritarian, centralised system that eliminates checks and balances to improve efficiency and get things done (Babiš 2017, 8, 126-131). Babiš advocates: the abolition of the Senate; the reduction by half of the number of representatives in the lower house; the scrapping of elected regional governments; and a 
move to a first-past-the-post electoral system. Voters would only elect their (very powerful) mayor and their parliamentary representative (Babiš 2017, 126-131, 134-135). Babiš has also spoken several times of a future two-party system in the Czech Republic where one party has ' $100 \%$ responsibility' for government. ${ }^{8}$ This vision of refashioning the Czech Republic's 'power dispersing' institutions to concentrate power and authority echoes the preoccupations of the political architects of illiberal, hybrid regimes such as Hungary's Viktor Orbán whose untrammelled authority Babiš is on record as admiring. ${ }^{9}$

ANO has so far not invoked the protection and promotion of an ethnically defined Czech nation. This distinguishes it from Fidesz and PiS for whom defending the "nation"understood in terms of ethnicity and socially conservative values - has been central to legitimising the concentration of power. The Slovak-born Babiš, whose sometimes Slovakinflected Czech is an indispensable part of his political brand, is an unlikely Czech nationalist. However, Babiš does not share any of the values associated with the traditional liberal vision of Czech nationhood (Auer 2004). His pronouncements on minority rights and the Czech nation often seem pragmatic or opportunistic. He has courted Czech voters with racist remarks vilifying Roma and other outsiders. His most notorious remark (later withdrawn with a weak apology) was that the Lety concentration camp where Roma were held during the Second World War was merely a labour camp, where inmates had to work hard. ${ }^{10}$ He has also promoted an 'economic nationalism' urging citizens to go 'Czech First' and 'Make Czechia Great Again' by recovering the dynamism, scientific excellence and can-do attitude of pre-communist Czechoslovakia. Babiš styles himself not only after Donald Trump, but also after Jan Antonín Bata, the interwar shoe magnate who had 
extensive (but never realised) plans in the 1930s to remake the country using management and business techniques (Babiš 2017, 11-12, 18, 119, 270-271). ${ }^{11}$

The ANO party has also used fear of refugees and Muslims to create a sense of external threat to Czech national identity, engaging in a bidding war with other Czech parties outdoing one another in their opposition to resettling a single refugee in the Czech Republic (Čulík 2017). Czech public opinion has long been hostile to the (theoretical) prospect of immigration from both EU and non-EU states. Babiš has fallen in step with president Zeman in arguing that although refugees and migrants have shown no interest in settling in the Czech Republic, the country will inevitably face massive migratory pressures threatening both its security and its way of life (Babiš 2017, 256). Like Zeman, Babiš argues that the EU should deal with the 'threat' of mass migration by securing its external border so that the Union resemble an 'Asterix village' (Babiš 2017, 254, 258, 261). Such views are, however, relatively mainstream in Czech politics and Babiš is no hard ideological Eurosceptic: he favours EU market infrastructure and security integration (Babiš 2017, 274, 279-30), while querying other aspects of integration as overlybureaucratic, constraining national sovereignty and competitiveness, or in need of reform. (Babiš 2017, 274-276). ${ }^{12}$ Despite fears that it might ally with the far-right Freedom and Direct Democracy (Svoboda a př́má demokracie, SPD) in government, in post-election negotiations in 2017 and 2018 ANO rejected the SPD as a potential coalition partner and refused to contemplate the central SPD demand of a referendum on Czech EU membership.

Thus far, in contrast to the nationalist rhetoric of Hungary's Fidesz and Poland's PiS, ANO's populism does not justify sharply centralising power and banishing political opponents in order to protect the nation. It has, for now, used the fight against corruption 
and 'traditional parties' and the 'elite establishment' as an effective stand in: Political consultation and compromise should be curtailed to actualise the business-like efficiency essential to modernising the state. However, ANO lacks the votes and seats to legislate such centralisation - much of which would require constitutional laws - and appears resigned to the fact that it has little immediate prospect of pushing through changes to the political system or constitution. Both the party election programme (ANO 2017) and the government programme presented to parliament by Andrej Babiš on 8 January 2018 made little mention of political reforms. ${ }^{13}$ ANO does, however, favour the introduction of citizeninitiated referendums, a measure also favoured by other parties (including ANO's prospective coalition partners, the Social Democrats). But the Czech Senate, where ANO has been weakly represented, is likely to block any constitutional law introducing binding referendums that bypass the legislative role of parliament. ${ }^{14}$

\section{ANO and patterns of power concentration}

An account of the formal legislative powers of ANO misses the power that it has accumulated elsewhere: in the state administration, in state-owned enterprises, in the police and security services, in large swaths of the economy, and in the media. As in Hungary and Poland, the success of a populist party that challenges the status quo in the Czech Republic has come hand in hand with concentrations of power that reinforce and amplify one another. In Hungary, in particular, the cultivation and creation of politically aligned oligarchs has been an important means for Fidesz to consolidate and extend its power since its initial electoral victory (Magyar 2016). But the Czech Republic stands out in two ways: the accumulation of economic and media power has preceded rather than followed a 
populist electoral challenge; and all of the power has accumulated into the hands of one person, Andrej Babiš. This raises the question whether the Czech Republic - rather than being a weaker, slower-motion version of backsliding in Hungary and Poland - exemplifies a different kind of backsliding altogether. In the following sections, we review how, step by step, Babiš has amassed and concentrated power in different areas over time and how these sequences interact.

Some authors have argued that the Czech Republic typifies a pattern of democratic erosion where elites captured the main post-1989 parties of left and right in order to capture the state (Innes 2014, 2016; Klíma 2015 Vachudova 2015). ${ }^{15}$ As Vachudova (2015: 525) observes, this second pattern is rooted in [an] endemic corruption problem: rent-seeking elites taking advantage of a weak rule of law and a weak state capacity to capture state institutions and funnel huge amounts of public money to private bank accounts. Some of this corruption is certainly organised by and around political parties - but it needs no constitutional majority to go forward, and in some areas it is agnostic about which political parties are in power.

However, the displacement by ANO of traditional parties has recast this debate. The issue is now less the consequences of party capture by decentralised networks. Instead, it is the concentration - and fusion - of private economic and media power with political power through the creation of a successful new populist party. The concentration of economic and media power has received less attention in the literature on backsliding than the concentration of political power. However, comparative researchers on economic oligarchies suggest that, even if legal, the interventions of super-rich individuals in politics 
skew public policy, distort the quality of democratic representation, and sap public trust in democracy (Winters 2011; West 2014) in ways which parallel the impacts of state capture (Tudoroiu 2015).

\section{Doing business with yourself: Agrofert and oligarchy}

While populist electoral victories in Hungary and Poland triggered oligarchical concentrations of economic power, in the Czech Republic oligarchical concentrations of economic power have triggered a populist electoral challenge with illiberal undertones. It is not surprising in hindsight that the Czech Republic yielded an oligarch-politician. While having a very equal society in terms of income distribution, the Czech Republic stands out in Europe for the relative wealth of its (dollar) billionaires, who owned assets in 2016 corresponding to just over $4 \%$ of national wealth, the highest of any EU/EEA state other than Sweden and Cyprus. ${ }^{16}$ Babiš, like most super-rich Czechs (see Roberts 2016b) made his initial fortune from the privatisation of state assets in the 1990s and early 2000s. In 1995, he bought up the Czech-based Agrofert subsidiary of the Slovak state-owned Petrimex foreign trade enterprise, where he had been an executive in the late communist period. ${ }^{17} \mathrm{He}$ steadily expanded Agrofert as a Czech-based conglomerate through a series of acquisitions of Czech state-owned companies and through state contracts facilitated by his political contacts with the 1998-2002 ČSSD government (Pergler 2014; Kmenta 2017; Vlasatá and Patočka 2017). There is strong circumstantial evidence that Babiš may have

covertly donated significant sums to ČSSD shortly before it entered government in 1998 (Kmenta 2017: locations 591-652). In this sense, as the investigative journalist Jaroslav 
Kmenta (2017) astutely notes, Babiš 'entered politics' not in 2011 when he founded ANO but in 1997-8 when he started intensively expanding his Agrofert conglomerate.

Agrofert Group has emerged as the Czech Republic's largest trading conglomerate, consisting of 256 firms dealing mainly in agricultural products, fertiliser, chemicals, and ground machinery. It is the largest private employer in the Czech Republic with 34,000 employees and had an estimated market value of 100 billion crowns ( $€ 3.7$ billion) in 2016, offset by debts of some 24 billion crowns ( $€ 890$ million) (Tramba 2016). Moreover, Agrofert companies have continued to do a great deal of business with the state, depending on public procurement and state subsidies for their profits. In 2014 alone they took in 3.1 billion crowns of public monies thanks to state contracts, state subsidies and EU subsidies. Babiš was Agrofert's sole owner until February 2017, when he transferred ownership to two family-controlled trusts to comply on paper with a new conflict of interest law. ${ }^{18}$

By the 2000s Babiš and Agrofert were one of half a dozen billionaire oligarch "families" exercising power over the country's parties and politicians (Best 2012), albeit obscured by the so-called "regional godfathers" - smaller corrupt business groups whose more publicised capture of the regional organisations of key Czech parties gave them growing political influence in mid-2000s (Klíma 2015). However, as Andrew Roberts's (2016b) survey of press interviews given by 32 (local currency) Czech billionaires between 2001 and 2016 confirms, most kept a low public profile and avoided open political engagement. This is in line with expectations: oligarchs in most political contexts are expected to act politically to defend their wealth, typically so vast that all political decisions impact on their private business interests, in a variety of ways (Winters 2011; West 2014; Mayer 2016). But they are expected to assert their interests discretely using the services of 
lobbyists and lawyers in the wealth defence industry or by bankrolling non-governmental organisations (NGOs), politicians, or parties. They are not expected to vie for high office themselves (Reuter 2015; Markus and Charnysh 2017).

\section{ANO - The civic movement that wasn't}

In Hungary and Poland well-established conservative-national parties have organised and cultivated conservative civil society initiatives and movements. At the same time, they have aggressively attacked liberal NGOs and associations by delegitimising them as enemies of the nation, by defunding them, and by passing laws that undercut or eliminate them. In the Czech Republic, by contrast, Babiš successfully launched ANO as a new party with scant organisation as a 'business-firm' or 'entrepreneurial' party (Just and Charvát 2016; Kopeček 2016; Hloušek and Kopeček 2017) To smooth the way, Babiš tried to co-opt liberal civil society groups and well-known figures from the liberal intelligentsia instead of vilifying them (Kmenta 2017: locations 279-84).

ANO’s strategy has evolved over time. In 2011 Babiš envisaged that his new movement would mobilise significant grassroots support. When launching the ANO in September 2011 Babiš called for civic mobilisation against corruption akin to that of Civic Forum in $1989 .{ }^{19}$ However, these appeals had little popular resonance and there was no mass grassroots activism paralleling that of Orbán's Civic Circles and its successors. Instead, after an abortive attempt to ally with local and regional independents groups in the 2012 municipal elections to provide ANO with an instant grassroots base, ANO was reinvented in 2013 as a top-down formation with the superficial trappings of citizen

politics, most visible in its insistence that it is a 'political movement' and not a party. ${ }^{20} \mathrm{In}$ 
the absence of any grassroots mobilisation, Babiš sought to create the appearance of civic support by co-opting the anti-corruption and good governance messages of many local, liberal NGO’s.

In reality, however, the ANO party is a vehicle for Babišs's personal power, created from the top down by recruiting a loose alliance of technocrats and businesspeople at the elite level (Cirhan and Kopecký 2017). It sports a deliberately low membership, very little deliberation, and increasing control for Babiš over party lists and policies, ignoring even the policy advisors the party has appointed (Kaiser 2017; Kopeček 2016). In May 2016 it possessed a mere 2,859 members $^{21}$ - with a waiting list of 1,120 for membership along with a separate list of some 7,000 'registered sympathisers'. ${ }^{22}$ This ensured Babiš's complete personal control over ANO: the party's structure, its dependence on him for financing, and an internal culture of not challenging the leader-founder effectively block any internal challenges. Dissatisfied members exit the party (Kopeček 2016).

In the absence of grassroots activist support, Babiš has been creative and sometimes successful in co-opting voices in academia, journalism, and the existing NGO sector. This has served the twin goal of controlling criticism and adding to ANO's credibility as a reformist civic movement. His overtures to key figures in Czech civil society, especially those with a liberal dissident background, were well documented in the run up to the 2013 elections (Kmenta 2017). Following the pattern set by Public Affairs in 2009-10 (Kmenta 2011), ANO sought, in particular, to champion and co-opt the programmes and personnel of anti-corruption NGOs. In March 2013 Babiš endorsed and took over a set of nine proposals of the most prominent Czech anti-corruption NGOs working together under the name "The Reconstruction of the State" (Rekonstrukce státu or RS). ${ }^{23}$ 
Although there is no evidence that RS was thus suborned, even the appearance of being allied with Babiš damaged its credibility as a non-partisan civic group while simultaneously bolstering ANO's image. Babiš proposed installing the serving director of Transparency International as the new Minister of the Interior after the 2013 elections, a move blocked by the Social Democrats who gained the ministry in the coalition negotiations. Later Adriana Krnáčová, the executive director of the Czech office of Transparency International from 2002 to 2007, ran successfully for mayor of Prague 1 at the top of the ANO ticket in the October 2014 communal and senate elections; her association with Transparency International was prominent in the party's own campaign literature. ${ }^{24}$ So, while ANO's ally President Zeman has vigorously denounced NGOs in ways that mimic the Fidesz government in Hungary, ${ }^{25}$ as a governing party ANO did not turn to strident anti-NGO rhetoric, nor did Babiš renounce his support for the legal changes advocated by Reconstruction of the State. Seven of those changes were included in the coalition government's programme, although ANO ministers were unsuccessful in piloting any of the anti-corruption laws in their remit.

Babiš's career since 2014, however, also demonstrates that he sees little or no role for direct citizen input into either policymaking or broader democratic governance. What Babiš brings to Czech politics is a kind of "anti-politics" that celebrates the concentration of power in the hands of businesspeople, "experts" or managers - and discounts the participation of citizens and civic groups. Babiš has bristled, for example, against giving civic and interest groups space to air their views on state infrastructure projects and proposed cutting back their right to do so. ${ }^{26}$ Babiš himself even views the 1989 Velvet Revolution, which re-founded Czech democracy, not as an act of mass civic mobilisation, 
but rather as the result of a secret deal between Moscow, Czech communists, and dissident elites to put Václav Havel in power. ${ }^{27}$

\section{The media: buying it up, tamping it down}

Babiš's entry into politics as founder of a new party was paralleled by his strategic entry into the media, designed to compensate for his movement's lack of political and social implantation, and to insulate it from media scrutiny. Babiš's media acquisitions likely stem from the learning effects noted above: He understood from the rise and fall of the Public Affairs (Věci veřejné, VV) party that managing media scrutiny is a key to success. VV entered parliament in 2010 on an anti-corruption platform similar to ANO's, but rapidly fragmented when investigative journalists from the $M F$ Dnes newspaper exposed the control of VV by businessman Vít Bárta and his long-standing plans to use it as a vehicle to further his business interests (Havlík and Hloušek 2014; Havlík 2015; Kmenta 2011). The far wealthier Babiš cut that problem off at the pass through his purchase of MF Dnes in June 2013 in the run-up to the November 2013 parliamentary elections (Kmenta 2017).

The Czech media landscape, like that of other CEE states, changed dramatically owing to the 2008 financial crisis (Stetka 2012): Before the crisis, 80\% of Czech print media were controlled by foreign, mainly German, investors. During and after the crisis, foreign owners were replaced by local oligarchs who have used their media outlets to further their own business and political interests, and to reduce scrutiny of their activities (Reporters without Borders 2017). In 2013, Babiš acquired MF Dnes and Lidové noviny, two of the main Czech daily newspapers. Also part of his holdings are the most popular 
radio station in the country and the great majority of all of the free newspapers handed out in urban centres. Even if the newspapers themselves are selling fewer and fewer print copies, their free internet pages are a key source of information for Czech voters and opinion-makers. All together his media holdings make him the most influential person in the Czech media according to the rankings published in the January 2014 Czech edition of Forbes magazine (Lazarová 2014) owning media which reach between a third and a half of Czech adults (Kmenta 2017, 64-67).

Along with working to shape public opinion and build his own image, Babiš has used his newspapers and other media to pressurise and discredit rival political parties, often targeting individual politicians through selective coverage. ${ }^{28}$ There are many examples of Babiš interfering directly in the content of the media that he owns. Many journalists and editors at Lidové noviny and MF Dnes quit in protest of the loss of independence or interference. The release in May 2017 of secret recordings of Babiš did not leave any room for doubt: Babiš is heard strategising with a reporter at $M F$ Dnes about when and how to run damaging stories about a political opponent of ANO, based on information taken from police files obtained illegally by way of his contacts in the secret services and the police, discussed in more detail below.

Babiš also appears to have used his power as the Minister of Finance to silence media outlets that criticise him or his party. For example, in March 2014 Babiš threatened the server Echo24, which was founded by a former editor of Lidové noviny and which he considered a hostile publication, Babiš suggested that its main investor, Jan Klenor, could soon become the target of a financial investigation by the Czech state (Perkernová 2014). While Babiš later apologised (weakly) for this statement, within a week there was a 
financial audit of Echo24. As one article pointed out, statistically a business in the Prague 1 district is likely to be subject to a financial control once every 145 years (Banzl 2014).

\section{In government: controlling key posts in the ministries and exploiting the state}

ANO has accrued substantial power in and through the state administration since entering government in 2013, and it continued to do so after December 2017 when Babiš was appointed prime minister.

Whatever his party's rhetoric, Babiš certainly did not practice transparency or meritocracy in his appointments to ministries and state-owned enterprises in his role as a powerful member of the 2013-17 coalition government. ${ }^{29}$ And despite the passing of a stronger, new Civil Service Law in 2014, he appointed political allies and associates to staff the state as traditional parties had always done. As Finance minister, for example, he replaced the heads of both the Financial Administration of the Czech Republic (GFř) (also known as the Chief Tax Inspector), and the Financial Analysis Unit (FAÚ) with people close to Agrofert. Following the 2017 election, as prime minister designate, Babiš made clear that even after the minority government he formed in December 2017 was reduced to a caretaker role by failing to win a vote of confidence, he would go ahead with extensive

personnel changes across all government ministries and state agencies. ${ }^{30}$ Other potential targets are likely to be the boards of state-owned enterprises and, if an ad hoc parliamentary majority can be mustered, the public broadcaster Czech Television and the broadcasting regulator. This behind-the-scenes takeover of the state administration is considered by many as the most concerning aspect of the rise of ANO (Mazancová 2018). 
The positions that Babiš and his ANO associates held in government gave them the power to shape institutions and policies that regulate economic actors. By controlling the Ministry of Finance 2014-17, for example, Babiš controlled the state bodies tasked with inspecting the financial activities of Czech businesses and their compliance with Czech tax laws. This gave Babiš access to information about his political and business competitors and thus potential leverage over them. The introduction in December 2016 of the Electronic Record of Sales (EET) system under which most retail cash transactions are logged online in real time with tax authorities has put a still huger volume of information in the hands of the finance minister ( $\breve{v i h e l ~ 2016) ~}$

Concerns about Babiš misusing state power have also centred on his close relationships with police officers, prosecutors and the secret services, and the implications of these relationships for safeguarding the rule of law. These concerns have been exacerbated since ANO became the sole party of government in December 2017. In April 2018, when ANO was still the sole party in government, three of the country's leading investigative journalists, all of whom had written on Babiš’s business background, issued a joint statement complaining that police investigations into leaks of official information were being systematically manipulated intimidate them. ${ }^{31}$ Even with the sacrifice of the key interior ministry portfolio to a junior coalition partner in the proposed minority coalition with the Social Democrats agreed in May 2018, ANO will retain significant reach into the state administration and state agencies, including the public prosecutors' offices.

However, it has long been striking how many former high-level police and secret service officers have moved to the security division of Agrofert or to the helm of one of its companies over the past two decades or more (Neovlivni.cz. 2015; Slonková 2016; Kmenta 
2017: location 990-94). These hires by Agrofert have included officials working in special police units investigating corruption and organised crime as recently as 2015. The (mis)use of public and private security resources by politicians to build a power base and discredit or pressure opponents has been a recurring feature of Czech politics (Bureš 2015). However, it has hitherto been a strategy deployed by individual politicians or minor parties such as VV. Babiš used Agrofert to gather a critical mass of individuals with the power to misuse state information and blackmail state officials. These individuals have, with the rise of ANO, made a smooth transition to party politics and to government. This again underlines the synergies between concentrations of economic, party-political and governmental power - and the informal intelligence networks that span all three.

\section{Conclusion}

In this article, we have examined the case of Andrej Babiš and his ANO movement to understand whether and to what extent it is causing 'democratic backsliding' in the Czech Republic. We have looked especially through the prism of backsliding in Hungary and Poland, which has created a de facto paradigm for democratic regression in the region.

We show that the Czech Republic stands out in four ways. First, the sequence of events leading to the concentration of power has been different. In the Czech Republic, the accumulation of vast economic and media power has preceded rather than followed a populist electoral challenge. While Hungary's Fidesz is a party which has developed its own oligarchic networks after taking power, the Czech Republic's Babiš is an oligarch who has founded and developed his own party of power. Second, for ANO, power in the economy and the media served as a substitute for - or an alternative to - the political party 
and civil society structures built up by Fidesz and PiS. This power has been augmented by growing influence in the state administration and on the boards of state-run enterprises. Third, all this power has accumulated into the hands of one super-rich individual, Andrej Babiš. Fourth, the populism that Babiš and ANO have used to appeal to the voters is more technocratic than nationalist, organised around the fight against corruption by an establishment elite cabal. ANO does not evoke threats to the nation in the same ways as Fidesz or PiS, but does use fear of migrants and refugees, and partners with the Czech president whose xenophobia and anti-Western views are a centrepiece of Czech politics.

We also explore whether and how the concentration of power by Babiš and ANO is putting the Czech Republic on a path to democratic backsliding akin to what has happened in Hungary since 2010 and Poland since 2015. In writing, Babiš offers a vision of illiberal democracy with a technocratic rationale that involves centralising state power and stripping away checks and balances - all in the name of efficiency and modernisation to be achieved by 'running the country like a firm.' In his off-the-record remarks, Babiš characterises democracy as a struggle between elites, who stage manage and manipulate citizen participation. His background also signals a disregard for liberal democracy and rule of law. Babiš's career in the communist economic nomenklatura and subsequently in post-communist business was built by bypassing formal rules and trafficking with the state, based on the skilful accumulation and use of political and intelligence networks to outmanoeuvre and eliminate rivals. Babiš, however, has so far come up far short of the parliamentary majority won in watershed elections by Fidesz in 2010 and PiS by 2015 and is dependent on smaller parties to sustain a minority government. 
We, therefore, also considered whether exploitation of the state administration, enhanced by such enormous power in the economy and the media, represents a 'side door' to backsliding. The literature agrees that state capture and economic oligarchy distort democratic representation and undermine trust in democracy, but it is unclear if, on their own, they can erode liberal democracy sufficiently to establish an illiberal regime. Nevertheless, it is worth noting how much the power that Babiš has accumulated in the economy, in politics, in the media and in the state administration amplify one another, and echo the power structures put into place by conservative nationalist parties in Hungary and Poland after winning watershed elections in 2010 and 2015. There is also no question that the political rise of Andrej Babiš and ANO has undermined already weak informal liberaldemocratic norms in areas such as financial transparency, conflict of interest, manipulation of the state administration and accountability to the media (Grzymala-Busse 2017). 


\section{References}

ANO 2017. Ted' nebo nikdy. Ten jediný program, který potřebujete. Prague: ANO 2011.

Auer, S. 2004. Liberal Nationalism in Central Europe. Abingdon: Routledge.

Babiš, A. 2017. O čem snim, když náhodou spím. Prague: ANO.

Balogh, E. 2010. "Politics and the Media", Hungarian Spectrum, 29 April. Accessed 7 December 2017. https://hungarianspectrum.wordpress.com/2010/04/29/politicsand-the-media/

Banzl, M. 2014. "Je Babiš "český Berlusconi [Is Babiš the Czech Berlusconi?]"?", EuroZprávy.cz, $16 \quad$ September. Accessed 7 December 2017. http://domaci.eurozpravy.cz/politika/102380-je-babis-cesky-berlusconi/

Bermeo, N. 2016. “On democratic backsliding.” Journal of Democracy 27 (1): 5-19.

Best, E. 2012 “Skuteční kmotři. Pět rodin, které ovládají Česko [The real godfathers. The five families that control Czechia]”. 14 May, Aktualne.cz. Accessed 10 July 2017. https://nazory.aktualne.cz/komentare/skutecni-kmotri-pet-rodin-ktere-ovladajicesko/r i:article:744543/

Bernhard, M. 2017. "Introduction, European Forum: Democratic Deterioration in Central Europe." Newsletter of the European Politics and Society Section of the American Political Science Association. Winter, 3-13.

Bures, O. 2014. "Private Security Companies in the Czech Republic: Rearticulating the Security Field and Transforming Politics"' Security Dialogue 45 (1): 81-98.

Bustikova, L. and Guasti, P. 2018 "The State as a Firm: Understanding the Autocratic Roots of Technocratic Populism.” Unpublished paper. 
Cassani, A., and L. Tomini. 2018. Reversing regimes and concepts: from democratization to autocratization. European Political Science, 1-16. Advance online publication. https://doi.org/10.1057/s41304-018-0168-5

Cirhan, T., P. and Kopecký. 2017. "Career Backgrounds, Professional Network and Party Cohesion: The Success of ANO in the Czech Republic.” Politologický časopis Czech Journal of Political Science 24 (2): 116-136.

Císař, O. 2017. Czech Republic: from post-communist idealism to economic populism. Berlin: Friedrich-Ebert-Stiftung.

Crowther, W. 2017. "Ethnic Condominium and Illiberalism in Macedonia. East European Politics and Societies.” 31 (4): 739-761.

Čulík, J. 2017 "Why is the Czech Republic so hostile to Muslims and refugees?" Europe Now Journal. 2 September. Accessed 7 December 2017. http://www.europenowjournal.org/2017/02/09/why-is-the-czech-republic-sohostile-to-muslims-and-refugees/

Deegan-Krause, K. 2006. Elected affinities: democracy and party competition in Slovakia and the Czech Republic. Stanford, CA: Stanford University Press.

Deegan-Krause, K., and T. Haughton. 2010. "A Fragile Stability. The Institutional Roots of Low Party System Volatility in the Czech Republic, 1990-2009”. Politologický časopis-Czech Journal of Political Science 10 (3): 227-241.

Dzięciołowski, K. 2017. Is there a chance for a non-partisan media in Poland? Reuters Institute Fellowship Paper, University of Oxford. Online https://reutersinstitute.politics.ox.ac.uk/sites/default/files/201712/Is\%20there\%20a\%20chance\%20for\%20non- 
partisan\%20media\%20in\%20Poland\%20-

\%20Krzysztof\%20Dzieciolowsk\%20Paper.pdf

Erdmann, G. 2011. "Decline of democracy: Loss of quality, hybridisation and breakdown of democracy.” In Regression of Democracy? Edited by G. Erdman and M. Kneuer, 21-58. Wiesbaden: Springer.

Coppedge, M. 2017. Eroding Regimes: What, Where, and When? V-Dem Working Paper 2017:57. Accessed online 1 May 2018 https://ssrn.com/abstract=3066677 or http://dx.doi.org/10.2139/ssrn.3066677

Dresden, J. R., and M. M. Howard. 2016. “Authoritarian backsliding and the concentration of political power." Democratization 23 (7): 1122-1143.

Enyedi, Z. 2016. "Populist Polarization and Party System Institutionalization: The Role of Party Politics in De-Democratization.” Problems of Post-Communism 63 (4): 1-11.

Greskovits, B. 2015. "The hollowing and backsliding of democracy in East Central Europe." Global Policy 6 (S1): 28-37.

Greskovits, B. 2017. Rebuilding the Hungarian right through civil organization and contention: the civic circles movement. Florence: EUI Working Paper RSCA 2017/37, Robert Schuman Centre for Advanced Studies. Accessed 7 December 2017. http://cadmus.eui.eu/handle/1814/47245

Grzymala-Busse, A. 2008. "Beyond Clientelism Incumbent State Capture and State Formation." Comparative Political Studies 41 (4-5): 638-673. 
Grzymala-Busse, A. 2017. "Populism and the erosion of democracy in Poland and in Hungary." Paper presented at the conference "Global Populisms: A Threat to Democracy?" Stanford University, 3 November.

Hanley, S. 2016. "Something Rotten in the State of Czechia? Review Essay". Politologický časopis - Czech Journal of Political Science 23 (3): 272-279.

Hanley, S. and A. Sikk. 2016. "Economy, corruption or floating voters? Explaining the breakthroughs of anti-establishment reform parties in eastern Europe." Party Politics, 224: 522-533.

Haughton, T., and K. Deegan-Krause, 2015. "Hurricane Season: Systems of Instability in Central and East European Party Politics.” East European Politics and Societies, 291: 61-80.

Havlík, V. 2015. "The Rise of Party Populism in the Czech Republic". In European Populism in the Shadow of the Great Recession, edited by H. Kriesi and T. S. Pappas, 199-216. Colchester: ECPR Press.

Havlík, V., and V. Hloušek. 2014. "Dr Jekyll and Mr Hyde: the story of the populist public affairs party in the Czech Republic." Perspectives on European Politics and Society. 154: 552-570.

Havlík, V., and L. Kopeček. 2008. "Krize vládnutí v České republice. Analỳza pǔsobení volebního a stranického systému a návrhy možnỳch řešení. [A crisis of governance in the Czech Republic. An analysis of the working of the electoral and party systems and proposals for a possible solution" Politologickỳ časopis 15 (3): 183-205. 
Havlík, V and P. Voda, 2018. Cleavages, Protest or Voting for Hope? The Rise of Centrist Populist Parties in the Czech Republic. Swiss Political Science Review 24 (2): 161186.

Hloušek, V., and Kopeček, L. 2017. "Entrepreneurial Parties: A Basic Conceptual Framework." Politologický časopis - Czech Journal of Political Science 24 (2): 8391.

Innes, A. 2014. “The political economy of state capture in central Europe.” JCMS: Journal of Common Market Studies 52 (1): 88-104.

Innes, A. 2016. "Corporate State Capture in Open Societies: The Emergence of Corporate Brokerage Party Systems.” East European Politics and Societies 30 (3): 594-620.

Just, P. and J. Charvát. 2016. "Business-Firm Parties and the Czech Party System after 2010.” Politics in Central Europe 12 (3): 83-110.

Kaiser, Daniel. 2017. "Premierem ješte není. Sorry jako, [No longer prime minster. Well, sorry]" Echo24.cz, 3 March. Accessed 7 December 2017. http://echo24.cz/a/wUUKH/premierem-jeste-neni-sorry-jako

Kaltwasser, C. R. 2012. "The ambivalence of populism: threat and corrective for democracy." Democratization 19 (2): 184-208.

Klíma, M. 2015. Od totality $k$ defektní demokracii: privatizace a kolonizace politických stran netransparentním byznysem. [From totalitarianism to defective democracy: the privatisation and colonisation of political parties by non-transparent business] Prague: SLON.

Klimeš, D. 2016. "Liberál Verhofstadt chce Babiše premiérem a sebe předsedou europarlamentu [Liberal Verhofstadt wants Babiš to be prime minister and himself 
to be speaker of the European Parliament]". Ihned.cz, 8 December. Accessed 7 July 2017. $\quad$ http://zahranicni.ihned.cz/evropa-slovensko/c1-65549340-liberal$\underline{\text { verhofstadt-chce-babise-premierem-a-sebe-predsedou-europarlamentu }}$

Kmenta, J. 2011. Všehoschopni - superguru Bárta [Capable of anything - Bárta the superguru] . Prague: JKM.

Kmenta, J. 2017. Boss Babiš. Prague: JKM e-book.

Kopeček, L. 2016. “'I'm Paying, So I Decide Czech ANO as an Extreme Form of a Business-Firm Party”. East European Politics and Societies 30 (4): 725-49.

Kopeček, L. 2017. Miloš Zeman - př̉běh talentovaného pragmatika: Intelektuál válčí s intelektuály [Miloš Zeman - the story of a talented pragmatist: An intellectual at war with intellectuals]. Brno, Barrister and Principal.

Kopecký, P, 2004. “The Czech Republic: Entrenching Proportional Representation.” In The handbook of electoral system choice. Edited by J. Colomer, 347-358. Basingstoke: Palgrave Macmillan.

Lazarová, D, 2014. "Forbes: Andrej Babiš is most powerful person of Czech media world." Radio Prague, 3 January. Accessed 7 December 2017. http://www.ceskenoviny.cz/zpravy/andrej-babis-is-most-powerful-person-of$\underline{\text { czech-media-world-forbes/1025966 }}$

Levitsky, S., and D. Ziblatt, 2018. How democracies die. New York: Crown Publishing. Magyar, B. 2016. Post-Communist Mafia State. Budapest: Central European University Press.

Mayer, J. 2016. Dark money: how a secretive group of billionaires is trying to buy political control in the US. Brunswick, Victoria: Scribe. 
Mair, P. 2002. "Populist democracy vs party democracy." In Democracies and the populist challenge. Edited by Yves Meny, 81-98. Houndhills: Palgrave Macmillan.

Markus, S., and V. Charnysh 2017. “The Flexible Few: Oligarchs and Wealth Defense in Developing Democracies." Comparative Political Studies 50 (12): 1632-1665.

Mazancová, H. 2018. "Změny ve státní správě? Některé jsou protizákonné, kritizuje Babišovu vládu Rekonstrukce státu [Changes in the state administration? Some are unlawful says criticism of Babiš governmment by Reconstruction of the State." iRozhlas. 9 April. Accessed 1 May 2018 https://www.irozhlas.cz/zpravydomov/andrej-babis-statni-sprava-sluzebni-zakon-josefpostranecky_1804091245_hm

Mudde, C. 2004. "The populist zeitgeist." Government and Opposition 39 (4): 542-563. Mueller, J.-W. 2014. “Eastern Europe Goes South: Disappearing Democracy in the EU's Newest Members.” Foreign Affairs March/April, 14-19.

Neovlivni.cz 2015 "Bezpečnostní mapa Andreje Babiše [An Andrej Babiš security map" Neovlivní.cz, 21 June. Accessed 7 December 2017. http://neovlivni.cz/bezpecnostni-mapa-andreje-babise/.

Pappas, T. S. 2014. "Populist Democracies: Post-Authoritarian Greece and PostCommunist Hungary." Government and Opposition 49 (1): 1-23.

Patočka, J. 2017. "The best result from the Czech elections would be chaos." The Guardian, 20 October. $\quad$ Accessed $7 \quad$ December 2017. https://www.theguardian.com/commentisfree/2017/oct/20/best-result-czech$\underline{\text { republic-elections-chaos-andrej-babis }}$ 
Pehe, J. 2018 forthcoming. "Is there hope for liberal democracy in the Czech Republic?" Journal of Democracy.

Pergler, T. 2014 Babǐs. Přibeh oligarcha. [Babiš: the story of an oligarch] Prague: Mladá fronta.

Perkernová, K. 2014. “Sobotka: Nejčistší by bylo, kdyby Babiš přestal podnikat” [Sobotka: the cleanest solution would be if Babiš was no longer in business). Deník.cz 28 March. Accessed 7 December 2017. https://www.denik.cz/z_domova/sobotkanejcistsi-by-bylo-kdyby-babis-prestal-podnikat-20140328.html

Polk, J. J. Rovny, et. al. 2017. "Explaining the salience of anti-elitism and reducing political corruption for political parties in Europe with the 2014 Chapel Hill Expert Survey data." Research and Politics 4 (1): 1-9.

Reporters without Borders. 2017. “Local oligarch's conflicts of interest dominate Czech media”. 26 July 2017. Accessed 7 December 2017 https://rsf.org/en/news/localoligarch-conflicts-interest-dominate-czech-media

Reuter, T. 2015. "Political Parties and the Power of Money in Indonesia and Beyond". TRaNS: Trans-Regional and-National Studies of Southeast Asia 3 (2): 267-88.

Roberts, A. 2006. "What kind of democracy is emerging in Eastern Europe?." Post-Soviet Affairs. 22(1): 37-64.

Roberts, A. 2010. The quality of democracy in Eastern Europe: public preferences and policy reforms. Cambridge and New York: Cambridge University Press.

Roberts, A. 2016a. "What Do We Know and What Do We Need to Know about Mass-Elite Linkages in the Czech Republic?" Acta politologica, 8 (2): 31-50. 
Roberts, Andrew. 2016b. "Miliardáří a česká demokracie”. In Kvalita české demokracie, edited by Balík - Stanislav, Michal Pink, Andrew Roberts, Marek Rybář, Spáč Peter, Svačinová Petra, and Voda, Petr. 171-89. Brno: Centrum pro studium demokracie a kultury.

Roberts, A. 2017. "Czech democracy in the eyes of Czech political scientists." East European Politics 33 (4): 562-572

Rovny, J. 2017. "Election reaction: The Czech Republic shifts toward the Polish and Hungarian model." EUROPP blog. 23 October. Accessed 7 December. http://blogs.lse.ac.uk/europpblog/2017/10/23/election-reaction-the-czechrepublic-shifts-toward-the-polish-and-hungarian-model/

Sadecka, A. 2018. "Populist Anti-Semitism in Polish right-wing media narratives." Paper presented at the 4th International Populism Conference, Prague, 21-22 May.

Scheiring, G. 2015. "The Political Economy of De-Democratization in Hungary." Paper prepared for Conference of the European Sociological Association, Prague, 25-28 August.

Scheppele, K. L. 2013. "The rule of law and the Frankenstate: why governance checklists do not work." Governance 26 (4): 559-562.

Sitter, N, A. Batory, J. Kostka, A. Krizsan and V. Zenta. 2016. Mapping Backsliding in the European Union. Central European University Center for Policy Studies, Working Paper Series 2016/8, Budapest. Accessed 7 December 2017. http://www.transcrisis.eu/wp-content/uploads/2016/08/D6.1-MappingBacksliding-and-Report-on-Workshop.pdf 
Slonková, S. 2016. “Nová jména v bezpečnostní pavučině Andreje Babiše [New names in Andrej Babiš's security web]”. 5 May 2016. Accessed 7 December 2017. http://neovlivni.cz/nova-jmena-v-bezpecnostni-siti-ab/

Spurný, J. 2002. "The Richest Czech Keeps a Secret" Respekt, 13 May. Accessed 7 December 2017. https://www.respekt.cz/respekt-in-english/the-richest-czechkeeps-a-secret

Stetka, V. 2012. From Multinationals to Business Tycoons: Media Ownership and Journalistic Autonomy in Central and Eastern Europe. The International Journal of Press/Politics, 17 (4), 433-456.

Švihel_P. 2016. "Selžou spíše lidé než technika, varují před únikem dat z EET experti [People will fail, rather than technology, warn experts over data leaks from Electronic Record of Sales system]', Seznam.cz, 18 December 2016. Accessed 7 December 2017. https://www.seznam.cz/zpravy/clanek/selzou-spise-lide-neztechnika-varuji-pred-unikem-dat-z-eet-experti-7712

Tudoroiu, T. 2015. "Democracy and state capture in Moldova." Democratization, 22 (4), $655-678$.

Tramba, David. 2016. “Byznys Andreje Babiše: 5 postřehů z výroční zprávy Agrofertu [Andrej Babiš's business: 5 take-aways from Agrofert's annual report]”. Dotyk. 26 July. Accessed 8 July 2017. http://www.dotyk.cz/byznys/byznys-andreje-babise-5postrehu-z-vyrocni-zpravy-agrofertu-20160726.html

Vachudova, M.A. 2005. Europe Undivided: Democracy, Leverage and Integration After Communism. Oxford and New York: Oxford University Press. 
Vachudova, M.A. 2015. "External Actors and Regime Change: How Post-Communism Transformed Comparative Politics." East European Politics and Societies 29 (2): $519-530$.

Vachudova, M. A. 2017. "From Competition to Polarization in Central Europe: How Populists Change Party Systems and Change the EU'. Paper presented at the conference "Global Populisms: A Threat to Democracy?" Stanford University, 3 November.

Vlasatá, Z., and J. Patočka. 2017. Žlutý baron: skutečný plán Andreje Babiše: zřídit stát jako firmu [The yellow baron: Andrej Babiš's real plan to run the state like a firm]. Prague: Referendum.

Wagenknecht, Lukáš. 2017. "Proč nevyřeší svěřenský fond střet zájmů ministra financí? [Why don't the trust funds solve the finance minister's conflict of interest?]" Tyden.cz, 31 January 2017. Accessed 7 December 2017. http://www.tyden.cz/rubriky/nazory/komentatori/proc-nevyresi-sverensky-fond$\underline{\text { stret-zajmu-ministra-financi_415801.html }}$

West, D. M. 2014. Billionaires: Reflections on the upper crust. Washington, D.C.: Brookings Institution Press.

Winters, J. A. 2011. Oligarchy. Cambridge and New York: Cambridge University Press. 
${ }^{1}$ The case, which concerned EU subsidies claimed for Babiš's Stork’s Nest resort, could not proceed without parliament voting to strip him of the immunity from prosecution he (re-)acquired as deputy after being elected in October 2017. Prosecutors allege that Babiš and a group of associates and family members obscured the resort's real ownership to claim an EU grant intended only for SMEs. "Prosecution of PM Babiš to continue despite his complaint”. Prague Daily Monitor 3 May 2018. Accessed 1 June 2018 http://praguemonitor.com/2018/05/04/prosecution-pm-babi\%C5\%A1-continue-despite$\underline{\text { his-complaint }}$

2 For example, "Přibáň: Mocenské duo Zeman-Babiš by nás odsunulo na evropskou periferii. [Přibáň: duo of Zeman and Babiš in power will push us to the periphery of Europe]" Novinky.cz, 9 July 2017, https://www.novinky.cz/domaci/442911-priban$\underline{\text { mocenske-duo-zeman-babis-by-nas-odsunulo-na-evropskou-periferii.html }}$

${ }^{3}$ Fidesz was carefully preparing constitutional and legal changes in anticipation of its 2010 victory. Kim Lane Scheppele, personal interview, 12 October 2017.

${ }^{4}$ On Poland, interview with Jan Kubik, February 2018. This challenges earlier notions that CEE parties lacked the ability - or the incentives - to mobilise at the grassroots, and that civil society is always a bulwark against authoritarianism. 
${ }^{5}$ The Czech Republic also performed consistently well across V-DEM's more nuanced (2017) set of democracy indices which cover deliberative, participatory, and egalitarian forms of democracy, as well as measures of electoral and liberal democracy. Among CEE EU member states, it is usually ranked 1 or 2 . However, it lags somewhat behind in the Participatory Civil Society subcomponent, where it usually ranks 4-5.

${ }^{6}$ Although rivals during 1990s divided by conventional left-right divisions, Klaus and Zeman moved politically closer from late 1990s, because of a shared hostility to politicians in the liberal centre, overlapping views on the dangers of immigration and multiculturalism and an accommodating stance towards Putin's Russia.

${ }^{7}$ Babiš's movement was from the start publicly known as ANO2011, but it was formally first established as a civic association, the Dissatisfied Citizens' Action (Akce nespokojených občanů) in November 2011. This longer, protest-oriented name was, dropped when the movement registered as a political party on 15 May 2012 as ANO2011, with ANO as its registered abbreviation. Babiš had already registered the names Dissatisfied Citizens' Action, ANO2011 and four other variants of these as trademarks on 19 October 2011. See Pergler (2014: 132-133, 156 note 125).

8 “Andrej Babiš: Budou tu dvě strany, ČSSD a ANO [Andrej Babǐ̌; There will be two parties here - ČSSD and ANO ."Deník.cz 13 October 2014. Accessed 7 July 2017 http://www.denik.cz/z_domova/andrej-babis-budou-tu-dve-strany-cssd-a-ano-

20141013.html and "Vznikli jsme proto, abychom pomohli lidem, nebudeme to měnit [We formed to help people, we're not going to change that]" [Opening speech by Andrej Babiš 
to the III ANO congress] Parlamentní Listy.cz, 28 February 2015. Accessed 7 July 2017. http://www.parlamentnilisty.cz/profily/Andrej-Babis-12367/clanek/Vznikli-jsme-protoabychom-pomohli-lidem-nebudeme-to-menit-38882.

${ }^{9}$ For example, in remarks made to the Hungarian ambassador to the Czech Republic. Český žurnál: Matrix AB (TV film), Czech Republic, 2015, dir. Vít Klusák, http://bit.ly/2bdbRbN (accessed August 10, 2016, Remarks at 1:13:37.

10 "Babiš to před volbami zkouší, nemá informace, vadí Romům výrok o Letech [Babiš tries in out before elections, doesn't have information, offends Roma with remark about Lety." iDnes.cz 2 September 2016. Accessed 7 December 2017. http://zpravy.idnes.cz/romove-babis-koncentracni-tabor-lety-ds7/domaci.aspx?c=A160902_115045_domaci_ji (accessed 7 July 2017).

11 “Projev Andreje Babiše na celostátním sněmu [Andrej Babiš’s speech at the national $\begin{array}{lllllll}\text { congress]", } & 25 & \text { February } & 2017 . & \text { Accessed } & 7 & \text { July }\end{array}$ https://www.anobudelip.cz/cs/makame/aktuality/novinky/projev-andreje-babise-nacelostatnim-snemu-33634.shtml.

${ }^{12} \mathrm{He}$ does not support adopting the Euro, arguing that it would not benefit the Czech economy and that the Eurozone should first be reformed so the Czech Republic would not be liable for costly bailouts of fiscally weaker members. 
13 "Programové prohlášení vlády [Programme statement of the government]" 8 January 2018. https://www.vlada.cz/assets/jednani-vlady/programove-prohlaseni/Programoveprohlaseni-vlady-CR.pdf. The only proposed reforms were the introduction of postal voting and the abolition of second round run-offs in Senate elections.

14 "Referendum by zarazil Senát [Senate would block referendum]" Novinky.cz, 25 April 2018 https://www.novinky.cz/domaci/470239-referendum-by-zarazil-senat.html

${ }^{15}$ There are still many unresolved questions about whether corrupt party capture in and of itself as can subvert democratic representation, the rule of law and the legitimacy of democracy to such an extent that, they can cause backsliding as Klíma (2015) suggests; also see Hanley (2016).

${ }^{16}$ Authors' calculations. Dollar billionaires were listed for 20 EEA states in Forbes 2016. The Credit Suisse Global Wealth Report provides estimates of national wealth.

${ }^{17}$ The sources of investment for this initial privatisation remain unclear (Spurný 2002; Kmenta 2017).

${ }^{18}$ However, as trust administrators include close associates and family members, this amounted only to a cosmetic change in the ownership structure of Agrofert (Wagenknecht 2017).

19 “Babiš chystá Občanské fórum proti korupci a hledá lídra [Babiš plans Civic Forum against Corruption and seeks leader]."29 September 2011. Accessed 7 July 2017. 
http://www.ceskatelevize.cz/ct24/domaci/1241951-babis-chysta-obcanske-forum-protikorupci-a-hleda-lidra

${ }^{20}$ Czech party law maintains a formal distinction between a political party and a political movement dating from earlier legislation. However, the two are now legally identical for all practical purposes.

21 "Czech lawmakers override veto to curb Finance Minister Babišss business," Reuters, 11 January 2017. Accessed 7 December 2017. http://www.reuters.com/article/us-czechpolitics-babis-idUSKBN14V1I5

22 "Přrišli i prospěcháři, uznal Babiš. Ve volbách chce získat pět hejtmanů [Careerists have come too, admits Babiš. He wants to gain five regional governors in elections]," May 7, 2016. Accessed 10 August 2016. http://bit.ly/2bpvfTf and "Babišovu hnutí se denně hlásí 200 zájemců o členství [Babiš’s movement receive 200 membership applications daily]," novinky.cz, 23 August, 2013. Accessed 10 August 2016. http://bit.ly/2b5jFeu

23 "9 laws that will help end corruption". Accessed 7 December 2017. http://www.rekonstrukcestatu.cz/en

${ }^{24}$ Transparency International released a statement on its website that while "media outlets" were "making the link" between the work of Krnáčová at Transparency International (TI) and her campaign, she had had not had any connection to the organisation since 2007, and TI was in no way involved in her campaign. "TI does not want to be drawn into the election 


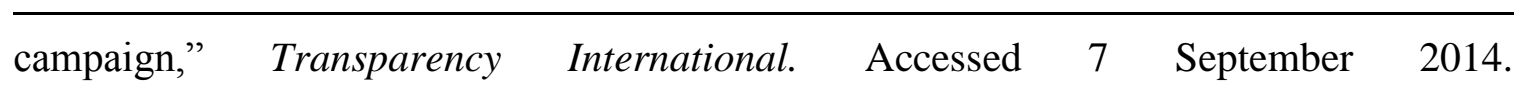
http://www.transparency.cz/ti-nechce-byt-vtahovana-do-volebni-kampane/

25 "Neziskovky jsou pijavice státu, myslí si Zeman [Non-profits are leeches feeding off the state, thinks Zeman]" Echo24, 6 June 2016. Accessed 7 December 2017. https://echo24.cz/a/wFDxx/neziskovky-jsou-pijavice-statu-mysli-si-zeman

26 “Babiš soptí: $\mathrm{K}$ dálnici se dneska vyjádřuje i jezevec. Jednou se $\mathrm{z}$ té demokracie poděláme [Babiš fumes: every last dachshund gets to express a view about a motorway. Some day this democracy is going to screw us up] "Parlamentní listy." 11 May 2013. Accessed 7 December 2017. http://www.parlamentnilisty.cz/politika/vlada/Babis-sopti$\underline{\text { K-dalnici-se-dneska-vyjadruje-i-jezevec-Jednou-se-z-te-demokracie-podelame-271563 }}$

27 “Havel i Kleslová jsou StB, rríká Babiš novináři v nově uniklé nahrávce [Havel and Kleslová were involved with communist secret police Babiš tells journalist in new leaked recording)". 28 June 2017. Accessed 10 July 2017 https://www.irozhlas.cz/zpravydomov/havel-i-kleslova-jsou-stb-rika-babis-novinari-v-nove-unikle-

nahravce_1706291156_kno. Babiš's account contains elements of conspiracy theories widely circulating in 1990s.

29 “Zákon měl zatrhnout politické trafiky. Babiš ho neumí napsat.” Aktualne.cz, 17 December 2014. https://zpravy.aktualne.cz/domaci/zakon-mel-zatrhnout-trafiky-politikubabis-ho-neumi-napsat/r ef336a3a844111e49f60002590604f2e/?redirected=1511170161 
30 ،Nabídku šéfovat ministerstvu průmyslu dostal Pustějovský, favoritem pro zdravotnictví je Vojtěch [Pustějovský gets offer to head ministry of industry, Vojtěch favourite for healthcare]" 21 September 2017. Accessed 7 December 2017. http://www.ceskatelevize.cz/ct24/domaci/2309269-nabidku-sefovat-ministerstvuprumyslu-dostal-pustejovsky-favoritem-pro-zdravotnictvi

31 “Investigativní novináři si stěžují na účelové policejní výslechy, ukazují na Babiše [Investigative journalists complain of being targeted by police questioning - and point to Babiš.” Novinky.cz, 6 April 2018 https://www.novinky.cz/domaci/468217-investigativni$\underline{\text { novinari-si-stezuji-na-ucelove-policejni-vyslechy-ukazuji-na-babise.html }}$ 